Eixo Roda, Belo Horizonte, v. 30, n. 1, p. 253-259, 2021

\title{
KOTECK, Davi. O que acontece no escuro. Porto Alegre: Editora Taverna, 2019.
}

\section{Jorge Vicente Valentim}

Universidade Federal de São Carlos (UFSCar), São Carlos, São Paulo / Brasil jvvalentim@gmail.com

http://orcid.org/0000-0002-9275-9801

O que tu tá fazendo aí, sozinho, guri?

Não sei. Eu apaguei.

Como assim?

Às vezes eu apago.

É?

Não sei explicar.

E o que acontece no escuro?

Fez uma curva grossa. Passei a sentir como se tudo escurecesse pela primeira vez.

(Davi Koteck. O que acontece no escuro)

Num dos textos mais emblemáticos para pensar a estética contemporânea e sua consolidação nas artes plásticas, na música e na literatura, Umberto Eco (1997, p. 37-38) propõe a presença obsidiante da "obra aberta" e suas múltiplas figurações, procurando observar a sua capacidade de não esgotamento total diante das variantes de leitura (sociológica, filosófica, psicanalítica, semiótica e teológica, por exemplo), em virtude de sua ambiguidade.

Para o semiólogo italiano, uma obra aberta deve ser compreendida enquanto objeto artístico com uma faculdade inesgotável de proporcionar vieses analíticos, na medida em que, no lugar de um "mundo ordenado segundo leis universalmente reconhecidas substitui-se um mundo fundado sobre a ambiguidade, quer no sentido negativo de uma carência de centros de orientação, quer no sentido positivo de uma contínua revisibilidade dos valores e das certezas" (ECO, 1997, p. 47).

Nada mais justo recuperar o autor de Obra aberta para tecer algumas reflexões em torno do primeiro livro do jovem escritor brasileiro Davi Koteck. Com textos seus já publicados na São Paulo Review (2019), 
Mallarmargens (2020) e Qualquer ontem (2019, antologia), Davi Koteck estreia com a coletânea de contos $O$ que acontece no escuro (2019). Mesmo se tratando de uma obra inaugural e com uma trajetória por trilhar, não se poderá negar que o presente título vem fazer companhia aos de outros nomes no cenário da novíssima ficção brasileira, sobretudo, no tocante às contribuições inventivas e renovadoras que esses têm imprimido nos últimos anos.

Ao lado de nomes emergentes e significativos, como os de Carol Bensimon (autora da "Apresentação"), Cristina Judar, Daniel Galera (responsável pela exposição da badana frontal), Felipe Franco Munhoz, Geovani Martins, Itamar Vieira Júnior, Jorge Ialanji Filholini, Natália Borges Polesso e Veronica Stigger, dentre outros, Davi Koteck consolida a sua entrada nesse expressivo grupo, investindo sobre o gênero conto.

Lidos em conjunto, os contos de $O$ que acontece no escuro podem ser compreendidos como pequenas peças cujos eixos giram em torno de temas viscerais e reverberativos, tais como o confronto com a solidão e a sensação de incompletude diante de relações ocasionais ("Campos neutrais" e "Pedaço de madeira"), a saída da casa dos pais e a formação da própria família ("Como se fumasse um cigarro"), o confronto com a morte e a percepção da pequenez da vida ("Led Zeppelin para dançar diariamente"), a compreensão do próprio corpo ("Para tão longo amor tão curta vida"), o alcoolismo ("Viver é fácil de olhos fechados"), a mediocritas do cotidiano e seus efeitos na formação do indivíduo ("No dia em que recolheram o Monza"), a hipervalorização de datas festivas e a futilidade dos consumismos ("Antinatal"), os dilemas da adolescência, como a vida sexual, a gravidez precoce e o aborto ("Use o assento para flutuar"), os conflitos deflagrados diante da descoberta da doença ("Nine out of ten"), as relações afetivas entre pessoas com diferença de idade ("Um pouco estranhos"), a separação dos pais pelo divórcio ("Mais traído do que nunca"), as ambiguidades entre amizade e relação homoafetiva, ainda que momentânea ("E ele sempre chegava"), a descoberta da homossexualidade do irmão ("O meu irmão"), a sensação pendular de estar entre o delírio e a realidade ("O que acontece no fim"), a orfandade ("O que acontece no escuro"), a solidão e a sensação de blackout ("O caminho de casa nunca foi tão escuro quanto agora").

Numa primeira leitura, é possível detectar a autonomia dos textos e sua independência em relação aos demais. No entanto, a insistência 
num narrador autodiegético em todos eles não deixa de abrir uma outra possibilidade de leitura na arquitetura de $O$ que acontece no escuro. Ainda que entenda a obra, tal como configurada desde a página frontal, como uma recolha de contos do autor, fico a me interrogar se todas as experiências narradas por uma primeira pessoa não poderão ser lidas como um grande mosaico de um mesmo “eu”, uma espécie mesmo de distensão narcísica, que, a cada página e a cada trama, tem de se confrontar com choques inevitáveis de sua realidade cotidiana.

Não à toa, todos esses eus protagonistas, volta e meia, esbarram em aventuras afetivas e sexuais furtivas com jovens de mesmo nome Ana, Flávia e Júlia reaparecem de um conto para outro - do mesmo modo como algumas referências espaciais em comum são recuperadas - as salas de aula da faculdade, as festas e os consultórios médicos para a recepção do diagnóstico de alguma doença -, deixando no leitor muito mais uma sensação de continuidade do que de arquitetura individual e desligamento. Mesmo assim, o mais interessante nesse caso é que os textos mantêm a sua autossuficiência de universo distinto, tanto do conto antecedente quanto do posterior.

Um dos pontos mais instigantes é a construção das personagens femininas, porque elas têm uma função primordial nas tramas. São elas que deflagram a visível necessidade do(s) protagonista(s) em exorcizar os fantasmas da solidão e da ausência, além de serem elas as que conseguem compartilhar uma parcela das aventuras experimentadas. Ana, por exemplo, aparece nos contos "Campos Neutrais", "Pedaço de madeira" e "O que acontece no fim"; Flávia surge em "Para tão longo amor tão curta a vida" e "O que acontece no fim"; Júlia, em "No dia em que recolheram o Monza", "Como se fumasse um cigarro só que ao contrário", "Um pouco estranhos", "Ele sempre chegava" e "O caminho de casa nunca foi tão escuro quanto agora". Outras, com apenas uma aparição, não deixam também de exercer a função de desencadear sentimentos cáusticos e corrosivos, como acontece com Laura, em "Led Zepelin para dançar diariamente"; Lúcia, em "Use o assento para flutuar"; e Amanda, em "Nine out of ten".

Do mesmo modo, essa técnica de valer-se do outro para expor e expurgar sentimentos e sensações de desassossego e, ao mesmo tempo, de necessário confronto também pode ser constatada nas personagens com laços familiares, como ocorre com as figuras da mãe, em "O que acontece no 
escuro", e do pai, em "Viver é fácil de olhos fechados", "Como se fumasse um cigarro só que ao contrário", "Antinatal" e "O meu irmão". Ao contrário das jovens com quem desenvolve laços de afinidade e sintonia, os familiares são todos inominados, quase uma sugestão da pouca intimidade entre eles, com uma exceção apenas, no conto "O meu irmão".

Aqui, é preciso estar atento para não cair numa armadilha em considerar tanto as figuras femininas de maior, quanto as de menor aparição, como meras repetições entre si de situações marcadas pelo desengano, pelo desencontro e pela transitividade do tempo. De forma muito engenhosa, o autor vai alterando as cenas de encontro, de desenvolvimento de relacionamentos e de desfechos entre ele e as jovens, não permitindo, na verdade, qualquer tipo de reincidência, a ponto de as transformar em autênticas e "multíplices perspectivas" (ECO, 1997, p. 40). Só assim consegue explorar a possibilidade de entrada do seu receptor, com "uma situação existencial concreta, uma sensibilidade particularmente condicionada, uma determinada cultura, gostos, tendências, preconceitos pessoais, de forma que a compreensão da forma originária se verifica segundo uma determinada perspectiva individual" (ECO, 1997, p. 40).

Sem querer roubar o prazer da leitura, não resisto em deixar dois exemplos sintomáticos, a fim de confirmar a minha perspectiva de entender os contos, no seu conjunto, como pequenas "obras abertas". O inevitável atrito com a homossexualidade alheia concede ao texto uma ambiguidade ímpar, nas duas vezes em que o tema surge em $O$ que acontece no escuro.

Em "E ele sempre chegava", a presença do amigo de Júlia expõe uma diferença gritante entre esse e o protagonista, ao ponto de suas orientações sexuais emergirem como campos bipolares e incomunicáveis: "No que ele era colunista da Veja, eu, Adorno. Quando ele dizia bossa nova, jazz. Phil Collins, Cohen. Karnal, Camus. Cerveja, eu, vinho. Ele gay e eu, hétero" (KOTECK, 2019, p. 84).

A partir dessa diferença, a incomunicabilidade parece ser a única tônica possível, no entanto, no lugar de apelar para uma certeza absoluta, o narrador-protagonista prefere deixar a dúvida como forma de entender as ambiguidades humanas: "Ele pôs a mão na minha coxa e meu pau começou a formigar" (KOTECK, 2019, p. 85).

O passeio de carro até a praia, do narrador autodiegético com o seu "quase" amigo, pode ser lido, nesse sentido, como uma metáfora da 
própria trajetória pela qual o sujeito precisa passar para compreender as sutis nuances que as sexualidades insinuam. Não à toa, o protagonista, que nunca havia fumado, pede um cigarro e sorve quase todos até a chegada no destino final. Exatamente ali, à beira-mar, as reticências surgem como instrumento funcional para entender as volúveis fronteiras que o narrador considerava certas e intransponíveis:

Agora era mais tarde ainda, só eu e ele na praia, ele me olhava com os olhos gordos e meu pau pulsava na calça como se bombeasse sangue pro resto do corpo. Eu disse que era hora de ir, e ele ficou quieto mais uma vez. Deu dois passos pra frente e me encarou bem de perto. Eu respirei fundo e senti o cheiro da Júlia, nunca tinha percebido o quão parecido eram os olhos deles. (KOTECK, 2019, p. 87).

Interessante observar que, como em outros contos, a percepção das coisas e do meio se dá não apenas pela visão, mas, sobretudo, pelo olfato, através do qual o protagonista consegue um grau de apreensão e de convivência do/no mundo. É claro que tudo não passa de pura insinuação, mas, por detrás da dissimulação, se é possível pensar numa fluida fronteira entre a amizade e a homoafetividade dos dois rapazes, isso só se torna plausível, graças à capacidade do autor em projetar uma "germinação contínua de relações internas” (ECO, 1997, p. 64), de que o leitor necessita para chegar à sua conclusão.

Acredito que, aqui, reside a bem-sucedida artimanha de Davi Koteck, porque consegue sugerir sem explicitar, apenas indicando possibilidades de leitura para o desfecho da trama. Ora se pode optar por uma inquestionável heterossexualidade do narrador e os reflexos da ereção como uma reação em cadeia, ora não deixa de ser cabível o impasse em que ele próprio se vê, ao notar a sua excitação não com Júlia, mas com um amigo dela.

É, portanto, a capacidade de desenvolver uma "percepção da totalidade dos estímulos" (ECO, 1997, p. 64) o principal recurso desenvolvido pelo autor, ao longo desse conto. Mais interessante se torna, porque, no seguinte, "O meu irmão", novamente o protagonista precisa se confrontar com a homossexualidade, mas não levando em conta as reações do seu próprio corpo, mas no do seu irmão mais velho e com a mesma carga de insinuação, instando o leitor a participar, "descobrir e escolher" (ECO, 1997, p. 64) a carga total de soluções plausíveis para os impasses efabulados na trama. 
A carga memorialística constitui uma tônica não apenas desse, mas de outros contos de $O$ que acontece no escuro. Talvez, por isso, para tentar deixar essas lembranças na órbita da impessoalidade, o irmão também é inominado, porque, muito mais importante que a certeza do nome, é a dúvida salutar que a personagem instaura no universo familiar do narrador.

Da ausência da mãe (terá sido aquela acidentada no conto homônimo "O que acontece no escuro"?) à orfandade e, consequentemente, à mudança para um possível lar adotivo (ou não), não há certezas expostas: "Depois, fomos morar com um homem mais velho que se chamava de pai, embora meu irmão o chamasse sempre pelo primeiro nome" (KOTECK, 2019, p. 89). Igualmente, movido por uma tentativa de recuperação das ruínas de um passado familiar, o narrador insinua o choque entre o pai e o irmão sem descrever qualquer detalhe mais preciso sobre o embate:

Teve uma vez que chovia tão forte ao ponto de ouvir o barulho das gotas. O homem mais velho abriu o quarto do meu irmão e disse que porra é essa, cara. O resto da conversa não deu para escutar, porque o barulho da chuva martelando o telhado era mais alto do que o eco da gritaria. (KOTECK, 2019, p. 89-90).

Ora, o autor consegue prender a atenção do leitor e inseri-lo nas soluções possíveis para entender as razões da saída do irmão da casa. É o que ocorre quando esse ressurge, numa das visitas, acompanhado de Flávio, um homem "mais velho do que ele, mais magro do que ele, e tinha a barba turva, cheia de redemoinhos", e apresenta-o como "alguém muito especial, e lembro de pensar se ele era mais especial do que eu, mesmo sabendo a resposta" (KOTECK, 2019, p. 91). Somente na última despedida, alguma certeza esboça-se:

Antes do funeral do meu irmão, meu pai ficou ajoelhado em casa, perto do tanque. Dirigi até o cemitério em terceira marcha, e a lomba da rua pareceu uma linha plana. Flávio estava ao lado esquerdo do caixão, usava um blazer preto amassado, tinha os olhos gordos, a mesma falha na barba, o espaço que sobrava na bochecha. Pus a mão nos ombros dele, dei um beijo seco na testa e senti na hora um cheiro afogado de sabão em pó. (KOTECK, 2019, p. 91).

Não à toa, a memória afetiva do narrador remete exatamente ao cheiro de "sabão em pó", sentido por ele quando criança, toda vez que o seu 
irmão lavava as suas roupas depois de brincar na areia. Logo, se a relação homoafetiva do irmão não surge explicitamente nomeada, isso não quer dizer que ela não seja a causa do desentendimento com o pai e o motivador de sua relação com Flávio. Ou será mera coincidência o fato de esse ir "ao lado esquerdo do caixão", no sepultamento do irmão mais velho?

Longe de se colocar numa posição judicativa, o narrador prefere compreender que o mundo é feito de diferenças e heterogeneidades, num desfecho extremamente sensível e poético, dando abertura não para a incompreensão e o ódio, mas para o respeito e o afeto.

Ainda que os contos de $O$ que acontece no escuro abordem temas corrosivos e mordazes, creio que, por detrás dessa escuridão, o autor sinaliza com o amor e a felicidade, enquanto sinônimos da/na experiência humana, sem barreiras de orientação sexual ou classe social. Nesse sentido, não seria essa possibilidade de vislumbrar um horizonte positivo uma das qualidades efabulatórias das tramas desse jovem escritor?

Daí a minha aposta em ler esses textos de Davi Koteck como autênticas joias por onde uma obra aberta se realiza, porque neles, também, se vislumbra uma ambiguidade da "existência social como choque de problemas não resolvidos” (ECO, 1997, p. 50). Será isso a marca de uma "pedagogia revolucionária" (ECO, 1997, p. 50)? Não sei, mas apostaria que sim, mesmo sabendo que só o tempo poderá confirmar. Para já, deixo o convite para essa belíssima estreia do jovem escritor Davi Koteck, afinal, como muito sabiamente anuncia a epígrafe, de Tiago Ferro (cf. KOTECK, 2019, p. 5): "também somos feitos de espaços em branco".

\section{Referências}

ECO, Umberto. Obra aberta: forma e indeterminação nas poéticas contemporâneas. Tradução de Giovanni Cutolo. São Paulo: Perspectiva, 1997.

KOTECK, Davi. O que acontece no escuro. Porto Alegre: Editora Taverna, 2019.

Recebido em: 15 de setembro de 2020.

Aprovado em: 11 de março de 2021. 